\title{
TANBIH AL-MASYI \\ MENYOAL WAHDATUL WUJUD: \\ KASUS ABDURRAUF SINGKEL DI ACEH ABAD 17 \\ KARYA OMAN FATHURAHMAN
}

(Review buku)

\author{
Zainuddin Abdullah \\ STIT Al-Amin Kreo Tangerang \\ zainuddinmh@gmail.com
}

\begin{abstract}
Abdurrauf's approach in interpreting the teachings of wahdatul exists by combining the opinions of the two leaders of the Sufism; philosophical satire and practical saga. Ibn Arabi, Abdurrahman al-Jami and Ibn al-Farid can be attributed to the philosophical satire whose mystical views are quoted by Abdurrauf. While al-Ghazali, alJunaid, al-Harawi, asy-Syadzili and Suhrawardi al-Baghdadi can be grouped together as characters of the Sufism who are also the backbone of his thinking. Oman Fathurrahman's study of Tanbih al-Masyi's text at least gives the impression that today's generation can see the text as Abdurrauf Singkel wrote it more than three hundred years ago. However, of course the research is complete if it is discussed Syatariyyah practices that contain a number of formulas or symbols of remembrance more intimately, thus rendering it more intact.
\end{abstract}

Keywords: Tanbih al-Masyi, Wahdatul Wujud, Aceh, Oman Fathurrahman.

\begin{abstract}
ABSTRAK
Pendekatan Abdurrauf dalam menginterpretasi ajaran wahdatul wujud yakni dengan menggabungkan pendapat para tokoh dari dua aliran tasawuf; tasawuf falsafi dan tasawuf amali. Ibnu Arabi, Abdurrahman al-Jami dan Ibnu al-Farid dapat digolongkan tokoh tasawuf falsafi yang pandanganpandangan mistisnya dikutip oleh Abdurrauf. Sementara al-Ghazali, al-Junaid, al-Harawi, asy-Syadzili dan Suhrawardi al-Baghdadi dapat dikelompokkan sebagai tokoh-tokoh tasawuf amali yang juga menjadi sandaran pemikirannya. Penelitian Oman Fathurrahman atas teks Tanbih al-Masyi setidaknya memberikan gambaran seakan generasi sekarang bisa menyaksikan kembali teks tersebut sebagaimana saat ditulis Abdurrauf Singkel, lebih dari tiga ratus tahun lalu. Tetapi, tentu saja penelitian tersebut terasa lengkap jika dibahas pula amalan-amalan Syatariyyah yang memuat sejumlah rumus atau simbol zikir secara lebih utuh, sehingga pemaparannya akan lebih utuh.
\end{abstract}

Kata Kunci: Tanbih al-Masyi, Wahdatul Wujud, Aceh, Oman Fathurrahman

\section{A. PENDAHULUAN}

Perkembangan pemikiran keagamaan di Indonesia memiliki corak beraneka ragam. Hal itu menjadi lazim apabila para ulamanya mengambil ilmu dari belahan negara di dunia. Dalam konteks ini adalah ulama Timur Tengah yang mempengaruhi pemikiran ulama Indonesia. Namun, pemikiran-pemikiran tersebut tidak begitu saja didapatkan dengan mudah, karena masih banyak karya-karya mereka yang masih berbentuk tulisan tangan yang belum terjamah secara pembacaan intelektual, di mana dalam hal ini dikaji melalui disiplin ilmu filologi.

Dengan semangat intelektual yang tinggi, penggalian atas berbagai pemikiran ulama nusantara dimaksudkan menjadi signifikan dalam konteks untuk memberikan gambaran tentang gejolak dan perkembangan pemikiran keagamaan yang terjadi saat itu. Dalam hal ini, Abdurrauf Singkel memiliki kedudukan penting bagi perkembangan Islam di Indonesia dalam interpretasinya mengenai tasawuf.

Atas dasar itu, penulis paling tidak sedikit berusaha mendeskripsikan intelektual muda, Oman Fathurahman yang telah 'menghidupkan'naskah ulama Indonesia yang belum banyak 
diketahui khalayak orang. Dan, yang dianalisa dan dideskripsikan penulis adalah format buku yang merupakan edisi terbit dari sebuah tesis dalam kajian filologi.

Sementara yang disertakan dalam bukunya Oman Fathuraman adalah dua topik utama; yaitu inventarisasi dan deskripsi naskah. Sementara dalam kajian filologi topik inventarisasi, deskripsi, dan perbandingan naskah merupakan nuansa yang sangat kental dalam filologi. Topik terakhir tidak disertakan dalam format bukunya Oman Fathurahman, sementara perbandingan - meski tidak secara langsung terwakili - naskah bisa dilihat pada tesis penulisnya.

Buku tersebut hadir ketika itu menurut penulisnya dalam rangka memperkenalkan mahasiswa IAIN Jakarta tempat penulis mengajar kepada kajian filologi, dimana memang filologi belum menjadi pilihan spesialisasi yang dapat dibanggakan. Dan seharusnya memang IAIN (ketika itu belum menjadi UIN) lah menjadi sentral dalam kajian naskah nusantara, dimana para mahasiswanya memiliki kemampuan bahasa Arab yang bisa dimanfaatkan dalam meneliti naskah-naskah berbahasa Arab.

\section{B. PEMBAHASAN}

\section{Sekilas tentang Ajaran Tasawuf dalam Tanbih al-Masyi}

Ajaran-ajaran tasawuf dalam teks Tanbih al-Masyi memberikan gambaran sosok Abdurrauf sebagai seorang ulama sufi yang ikut menyebarkan ajran Wahdatul Wujud atau Wujudiyah. Berdasarkan analisa Oman Fathurahman dengan kajian intertekstual ${ }^{1}$ dengan naskah-naskah lain karya Hamzah Fansuri, Asrar al-Arifin, Syarab al- 'Asyiqin dan al-Muntahi serta naskah karya ar-Raniri, Tibyan fi Ma'rifah al-Adyan dapat disimpulkan bahwa ajaran Wahdatul Wujud Abdurrauf dalam teks Tanbih al-Masyi mencerminkan sikap dan tanggapannya terhadap kontroversi doktrin wujudiyah yang terjadi di Aceh pada abad 17 antara ar-Raniri dan para pengikut ajaran wujudiyah Hamzah Fansuri dan Syamsuddin asSumatrani.

Memang, beberapa tanggapan Abdurrauf tidak dikemukakannya secara eksplisit dengan menyebut nama, apakah itu Hamzah Fansur, as-Sumatrani maupun ar-Raniri, namun dalam konteks Aceh saat itu, sulit untuk tidak mengaitkan pandangan-pandangannya tersebut dengan ketiga nama tersebut.

Lebih lanjut Oman - dengan mengutip pandangan A. H. Johns dan Drewes berpandangan bahwa kontroversi doktrin wujudiyah - merupakan konsekuensi pergulatan politik dan keagamaan di Moghul, India - ditanggapi Abdurrauf dengan sikap tidak cenderung kepada salah satu pihak yang bertikai, tetapi berdiri di tengah-tengah.

Pada satu sisi, Abdurrauf berusaha mengemukakan penafsirannya atas doktrin wahdatul wujud yang dapat dianggap sebagai bantahan atas ajaran Hamzah Fansuri dalam persoalan yang sama.

Sementara pada sisi yang berbeda, Abdurrauf juga mengecam tindakan radikal arRaniri yang telah memvonis para pengikut ajaran Hamzah Fansuri tersebut sebagai kafir, dan menelurkan fatwa untuk membunuh mereka.

Dalam analisa Oman Fathurahman, interpretasi Abdurrauf terhadap ajaran wahdatul wujud dimaksudkan agar ajaran tersebut dapat diterima oleh ulama sufi lain yang lebih ortodoks semisal ar-Raniri.

Abdurrauf - yang cenderung kompromistis - tampaknya tidak lepas dari pengaruh gurunya, yaitu al-Kurani, yang dikenal sebagai seorang juru damai yang lebih suka

${ }^{1}$ Teori intertekstual merupakan salah satu pendekatan dalam penelitian sastra yang menganggap bahwa suatu teks memiliki makna, bukan dalam keadaannya sebagai struktur yang mandiri, tetapi teks tersebut berkaitan dengan teks-teks lain. Teori ini berprinsip bahwa setiap teks sastra dibaca dan harus dibaca dengan latar belakang teks-teks lain, tidak ada sebuah teks yang mandiri, dalam arti bahwa penciptaan dan pembacaannya tidak dapat dilakukan tanpa adanya teks-teks lain. (Lihat Kristeva dalam Teeuw 1988:145-146, dan Oman Fathurrahman 1999:23) 
mendamaikan dua sudut yang bertentangan pendapat ketimbang memilih salah satu di antara keduanya.

Kendati demikian, tidak dikesampingkan begitu saja faktor kepentingan politik dalam sikap Abdurrauf ketika itu. Pasalnya, dalam masa pemerintahan Sultanah Safiyatuddin, Abdurrauf mendudukan jabatan sebagai Qadi Malik al-Adil yang bertanggung jawab terhadap berbagai permasalahan agama. Sebab itulah sebagai bentuk loyalitasnya kepada Sultanah, Abdurrauf memiliki kepentingan untuk meredakan ketegangan yang terjadi akibat kontroversi doktrin wujudiyah pada masa Sultan Iskandar Sani sebelumnya.

Pendekatan yang dilakukan Abdurrauf dalam melakukan interpretasi terhadap ajaran wahdatul wujud adalah dengan menggabungkan pendapat para tokoh-tokoh dari dua aliran tasawuf; tasawuf falsafi dan tasawuf amali. Ibnu Arabi, Abdurrahman al-Jami dan Ibnu alFarid dapat digolongkan tokoh tasawuf falsafi yang pandangan-pandangan mistisnya dikutip oleh Abdurrauf. Sementara al-Ghazali, al-Junaid, al-Harawi, asy-Syadzili dan Suhrawardi alBaghdadi dapat dikelompokkan sebagai tokoh-tokoh tasawuf amali yang juga menjadi sandaran pemikirannya.

Selain tentang doktrin wahdatul wujud, dalam Tanbih al-Masyi juga terdapat pandangan-pandangan Abdurrauf tentang tiga tahap pokok ajaran tarekat, ${ }^{2}$ yaitu penyucian diri yang dikemukakannya dalam seratus martabat, meditasi atau zikir, dan fana. Penyucian hati, sebagai tahap pertama tarekat Shattariyyah, oleh Abdurrauf diuraikan dalam sepuluh martabat, yang dalam setiap martabatnya terdiri atas sepuluh martabat pula, sehingga berjumlah seratus martabat. $^{3}$

Bahkan, Abdurrauf juga mengemukakan rumus-rumus - meminjam istilah Oman Fathurahman - khusus dalam tarekat Syatariyah yang hanya bisa dipelajari melalui mursyid (guru).

Seperti diketahui bahwa tarekat sufi dimulai sekitar abad ke-12. dan garis silsilah khusus mengambil nama-nama orang-orang suci utama yang dihargai sebagai pendiri tarekat ini. Salah satu bentuk tarekat yang muncul agak awal adalah tarekat Shattariyyah, pada abad ke-16, ${ }^{4}$ namanya disandarkan kepada nama Abdullah Shattari (w. 1428), yang berasal dari Asia Tengah dan Iran, dan dikembangkan di India, dimana Shattariyyah memimpin perkumpulan yang dekat dengan kerajaan Mughol. ${ }^{5}$

Abdullah Shattari, seorang 'Ulama' yang masih memiliki hubungan kekeluargaan dengan Syihab al-Din Abu Hafsh, 'Umar Suhrawardi (539-632 H/1145-1234 M), Ulama' sufi yang mempopulerkan tarekat Surhawardiyyah, sebuah tarekat yang awalnya didirikan oleh pamannya sendiri, Diya' al-Din Abu Najib al-Suhrawardi (490-563 H/1079-1168 M). Tarekat Shattariyyah ini diperkenalkannya di India oleh Beliau dengan menelusuri Lembah Gangga dengan berpakaian seperti seorang raja dengan pengikut-pengikut yang berpakaian yang seragam, membawa bendera dan memukul genderang untuk mendakwakan ajarannya. ${ }^{6}$

Selanjutnya, tarekat Shattariyyah berkembang ke Asia Selatan dan Arab. Bentuk khusus dicirikan dengan ketertarikan yang kuat kepada formula-formula meditasi yang bahkan meliputi nama-nama ketuhanan yang bukan berasal dari bahasa Arab, tapi berasal dari bahasa Persia dan Bahasa Inggris. ${ }^{7}$

${ }^{2}$ Secara kelembagaan, tarekat pada dasarnya tidak dikenal dalam Islam hingga abad ke-8 h atau abad ke-14 M. artinya tarekat sebagai oranisasi dalam dunia tasawuf, dapat diannggap sebagai hal baru yang tidak pernah dijumpai dalam tradisi Islam periode awal, termasuk pada masa Nabi. Tidak heran kemudian jika hampir semua jenis tarekat yang dikenal saat ini selalu dinisbatkan keapda nama-nama para wali atau Ulama' belakangan yang hidup berabad-abad jauh setelah masa lalu. (lihat Azyumardi Azra, Jaringan Ulama' Timur Tengah dan Keulauan Nusantara Abad XVII dan XVIII, (Bandung; Mizan, 1994), hal. 109.

${ }^{3}$ Tentang penyucian hati dalam dunia tasawuf, dikenal juga konsep maqamat (tahapan-tahapan) yang dikemukakan oleh Dzunnun al-Misri, yaitu taubah, Wara', Zuhud, Farq, Sabar, Tawakkal dan ridha. Tahapan-tahapan ini ditempuh oleh seorang sufi untuk sampai ketingkat melihat Tuhan dengan mata hati, dan akhirnya bersatu dengan-Nya.

${ }^{4}$ Annimarie Schimmel, Dimensi Mistik Dalam Islam, (Jakarta; Pustaka Firdaus, 1986), hal. 367-368.

${ }^{5}$ Carl W. Ernst, Mozaik Ajaran Tasawuf, (Jakarta; RajaGrafindo Persada, 1999), hal. 59.

${ }^{6}$ Syafiq A. Mughni, Dinamika Intelektual Islam Pada Abad Kegelapan, (Surabaya; LPAM, 2002), hal. 65.

${ }^{7}$ Carl W. Ernst, Mozaik Ajaran Tasawuf, hal. 59 
Jika ditelusuri lebih awal lagi, tarekat ini sesungguhnya memiliki akar keterkaitan dengan tradisi Transoxiana, karena silsilahnya terhubungkan dengan Abu Yazid al-Isyqi, yang terhubungkan lagi kepada Abu Yazid al-Busthami (w. 260 H/873 M) dan Imam Ja'far alShadiq (w. 146 H/763 M). tidak mengherankan kemudian jika tarekat ini dikenal dengan nama tarekat Isqiyyah di Iran atau tarekat Bistamiyah di Turki Uthmani, yang sekitar abad ke-5 cukup popular di wilayah Asia Tengah, sebelum akhirnya memudar dan pengaruhnya digantikan oleh tarekat Naqsabandiyah.

Tarekat 'Isqiyyah atau Bistamiyyah tersebut mengalami kebangkitannya kembali setelah Syah 'Abd Allah al-Shattar mengembangkannya diwilayah India, dan menyebutnya sebagai Tarekat Shattariyyah. Sejak itu, tarekat Shattariyyah selalu dihubungkan dengan jenis tasawuf India, kendati nama Abu Yazid al-'Isyqi dan Abu Yazid al-Bustami tetap menjadi sandaran dalam tradisi silsilahnya untuk menghubungkan sampai kepada Imam Ja'far alShadiq dan akhirnya sampai kepada Nabi Muhammad SAW.

Dalam konteks India sendiri, tarekat Shattariyyah -seperti halnya juga tarekat lain yang berakar di India yaitu tarekat Chistiyyah, tarekat Suhrawardiyyah, ${ }^{8}$ tarekat Firdausiyyah, dan tarekat Qadiriyah -muncul ketika berbagai gerakan keagamaan lebih memfokuskan misinya untuk melakukan ekspansi dakwah Islam kepada kalangan non Muslim. Di India, gerakan ekspansi semacam ini merupakan pariode awal dari keseluruhan gerakan keagamaan yang oleh para sarjana, umumnya dibagi kedalam empat kategori; pertama; gerakan "ekspansi" keagamaan dan kemasyarakatan, yang terjadi sekitar abad 6 H/12 M hingga abad $10 \mathrm{H} / 16 \mathrm{M}$, kedua; gerakan "reformasi" keagamaan dan kemasyarakatan yang terjadi sekitar abad $11 \mathrm{H} / 17 \mathrm{M}$, ketiga; masa "regenerasi" yang terjadi pada awal abad $12 \mathrm{H} / 18 \mathrm{~m}$, dan terakhir adlah masa "reorientasi" yang terjadi pada abad 19.

Sebagai sebuah gerakan ekspansi keagamaan, tarekat Shattariyyah pada periode ini lebih diarahkan pada perjuangan untuk meningkatkan nilai moral dan spiritual melalui penyebaran berbagai ajaran Islam. Dan dalam upayanya ini, Syah Abdullah al-Shattar berserta para pengikutnya mengembangkan kecenderungan untuk beradaptasi atau menyesuaikan diri dengan tradisi dan ritual masyarakat setempat yang masih banyak dipengaruhi ajaran ritual Hindu.

Memang, di satu sisi sikap akomodatif para penganut tarekat Shattariyyah seperti ini lebih mudah menarik perhatian nonmuslim untuk memeluk ajaran Islam, dan bahkan dianggap sebagai kunci sukses berkembangnya ajaran tarekat. Akan tetapi, disisi lain, hal ini juga mengakibatkan banyaknya konsep-konsep tasawuf dan ritual tarekat yang bersifat sinkretis serta memiliki persamaan dengan konsep-konsep dan ritual Hindu.

Syeikh Abdullah al-Shattar sendiri, sebagai pendiri tarekat Shattariyyah menetap di Mandu, sebuah desa di India bagian Tengah, dimana ia mendirikan khanqah pertama bagi para penganut tarekat Shattariyyah. Ia diketahui menulis sebuah kitab yang berjudul Lata'if AlGaibiyyah, tentang prinsi-prinsi ajaran-ajaran tarekat Shattariyyah yang disebutnya sebagai cara tercepat untuk mencapai tingkat ma'rifah. ${ }^{9}$ Karyanya ini kemudian disempurnakan oleh dua murid utamanya, Sheikh Muhammad 'Ala, yang dikenal sebagai Shaykh Qadi Bengal (Qazam Shattai) dan Shaykh Hafiz Jaqnpur. Yang disebut terakhir tercatat sebagai murid Syikh 'Abdullah yang berjasa mengembangkan silsilah tarekat Shattariyyah di India bagian Utara melalui muridnya, Syeikh Budhdhan. Belakangan, murid spiritual dari Sheikh Budhdhan ini, yakni Sheikh Baha' al-Din, menulis pula sebuah kitab berjudul Risalah Shattariyyah, yang berisi tentang prinsip-prinsip ajaran tarekat Shattariyyah.

Dalam perkembangan yang selanjutnya, tarekat ini berkembang pesat dan banyak dikenal sampai sekarang, terutama dikawasan Aceh Indonesia dibandingkan di Negara-negara lainnya. Salah satu 'Ulama' dalam bidang tasawwuf adalah Syekh Abdur Ra'uf Singkel bin 'Ali al-Fansuri atau disebut juga dengan Syekh Abdur Ra'uf Shi'ah Kuala (Singkel, 1035 H/1615

\footnotetext{
${ }^{8}$ J. Spencer Trimingham, The Sufi Order In Islam, (London; Oxford New York, 1973), hal. 96-97.

${ }^{9}$ The Sufi Order In Islam (London; Oxford New York, 1973), hal. 153-154.
} 
M - Banda Aceh 1105 H/1693 M). 'Ulama' besar dan tokoh tasawwuf dari Aceh yang pertama kali membawa dan mengembangkan Tareqat Shattariyyah di Indonesia. ${ }^{10}$

\section{Inventarisasi Naskah Tanbih al-Masyi}

Terdapat empat naskah yang diinventarisir oleh penulis; dua diantaranya di Perpustakaan Nasional Jakarta. Sementara dua lainnya di Perpustakaan Universitas Leiden. Hal ini berdampak kepada perbedaan catatan dalam katalog dan sumber yang berlainan

Naskah yang ada di Jakarta:

Naskah pertama terdaftar dalam katalog : Van Ronkel dengan nomor urut : 289

Naskah ini berada dalam urutan : ke-19 dari 24 teks dalam bundel naskah A 655.

Naskah kedua terdaftar dalam kalalog: Van den Berg sebagai salah satu dari 21 teks yang terdapat dalam bundle naskah A 101.

Naskah yang ada di Leiden:

Naskah pertama terdaftar dengan kode : Cod. Or. 7031

Naskah kedua terdaftar dengan kode : Cod. Or. 7030

Demi memudahkan, penulis melakukan indentifikasi dengan memberikan kode naskah berdasarkan urutan usia naskah:

MS A : A 655

MS B : A 101

MS C : Cod. Or. 7031

MS D : Cod. Or. 7030

\section{Deskripsi Naskah}

\section{MS A}

MS A merupakan urutan ke-19 dari 24 teks dalam naskah A 655. Judul yang diberikan oleh van Ronkel untuk naskah ini adalah at-tariqah asy-Syatariyyah, bukan tanbih al-Masyi. Justeru judul Tanbih al-Masyi terdapat dalam kolofon naskah tersebut.

Nama pengarangnya (seperti dalam kolofon): Abd ar-Rauf ibn Ali al-Jawi. Sementara penyalinnya - diduga kuat menurut Oman Fatrhurahman - adalah Abu al-Fath ibn asy-Syaikh Said al-Hajari al-Humadi al-Makky. Pasalnya, meski dalam kolofon naskah tidak disebutkan nama tersebut dijumpai sebagai penyalis beberapa teks dengan tulisan sama yang termasuk dalam bundle naskah A 655. Petunjukknya adalah kata "alMakky" yang terdapat di belakang nama penyalin tersebut, dan ini menjadi titik kemungkinan bahwa naskah tersebut disalin di Makkah.

Teks MS A disalin malam Sabtu, 10 Muharram 1158 H/12 Februari 1745 dari teks aslinya yang ditulis pada 5 Rabi'ul Awwal $1081 \mathrm{H} / 23$ Juli $1670 \mathrm{M}$.

Teks MS A tersimpan di Perpustakaan Nasional RI, Jakarta. Sementara di Leiden dalam bentuk microfilm dengan kode : Cod. Or. A.

Alas yang digunakan dalam MS A: fisik kertas terlihat lapuk, kekuning-kuningan, bolong.

Secara keseluruhan, kertas yang digunakan dalam MS A sudah dilaminasi untuk menghindari kerusakan yang lebih parah.

Cap kertas ditemukan pada beberapa halaman folio berbentuk gambar 3 buah bulan sabit.

Menurut analisa penulisnya, gambar tersebut menunjukkan bahwa kertas tersebut diproduksi di Italia pada paruh pertama abad 16.

Setiap halaman MS A terdapat tujuh buah garis tebal dengan posisi horizontal, dimana jarak antar garisnya adalah $3 \mathrm{~cm}$. sementara jarak antara garis tebal pertama dan keenam adalah $15,8 \mathrm{~cm}$. sedangkan garis tipis ditemukan dalam posisi sebaliknya sebanyak 8 buah garis dalam setiap satu sentimeter.

\footnotetext{
${ }^{10}$ Quraish Shihab et. al., Ensiklopedi Islam, (Jakarta; Ikrar Mandiriabadi, 1999), hal. 29.
} 
Teks Tanbih al-Masyi dalam MS A yang dianalisa Oman Fathurahman berukuran 17 x $10 \mathrm{~cm}$, sementara naskahnya sendiri berukuran $20 \times 16 \mathrm{~cm}$, dengan tebal 13 lembar folio.

Jumlah baris dalams etiap halaman berbeda-beda, ada yang 24 baris, yaitu ada yang 27 baris, 29 baris, 28 baris.

Teks dalam MS A menggunakan bahasa Arab, tanpa harakat dengan khat naskhi dan sedikit bergaya farisi.

Sebagaimana yang dianalisa Oman bahwa teks MS A pernah dimiliki oleh Abdullah bin Abdul Qahhar al-Jawi, yang terkenal sebagai pengarang dan penyalin berbagai naskah dalam perpustakaan kraton Banten, ia juga terkenal sebagai guru Syatariyyah.

Selain itu, juga terdapat kata-kata persembahan dalam bahasa Bugis dengan aksara Arab pada halaman paling depan bundel naskah A 655. Menurut Oman, hal itu menunjukkan bahwa naskah ini pernah berada di Sulawesi Selatan. ${ }^{11}$

\section{MS B}

Naskah MS B merupakan salah satu dari 21 teks yang terdapat dalam naskah A 101. Sedangkan 20 teks lainnya, sebagian tidak diketahui pengarangnya, dimana sebagiannya diduga kuat sebagai karya-karya Syekh Yusuf al-Makassari (lihat, Nabilah lubis, 1996).

Dalam naskah MS B terdaftar dengan judul Tanbih al-Masy. Sementara dalam kolofonnya tertulis Tanbih al-Masyi al-Mansub ila Tariq al-Qusyasyiy dengan pengarangnya Abdurrauf Ali al-Jawi.

Penyalinan naskah ini selesai pada hari Jum'at, 19 Rajab 1186 H/16 Oktober 1772 M. Nama penyalinnya tidak disebutkan.

Naskah MS B seperti yang telah diteliti Oman Fathurahman kini tersimpan di Perpustakaan Nasional RI, Jakarta.

Naskah MS B dalam bentuk mikrofilmnya terdapat di Leiden dengan kode Cod. Or. A 13d.

Alas naskah MS B berupa kertas yang kondisinya masih baik, tebal, kekuningkuningan, bersih tanpa ada coretan. Seluruh kertas tersebut dijilid dengan kertas tebal berwarna coklat kehitaman.

Cap kertas dalam naskah MS B terdapat pada setiap lembar folio berupa gambar yang termasuk kategori HORN, dan terletak di tengah-tengah gambar sebuah mahkota dengan tulisan D \& C BLAUW. Menurut Oman Fathurahman dengan mengutip pendapat Churchill bahwa dengan tanda seperti itu berarti menunjukkan bahwa kertas tersebut diproduksi di Belanda pada abad 18, tepatnya setelah tahun 1717 M.

Dalam setiap halaman MS B terdapat 9 buah garis tebal dengan posisi horizontal, dimana jarak antar garisnya adalah $2,5 \mathrm{~cm}$. sementara jarak antara garis tebal pertama dan keenam adalah $13,2 \mathrm{~cm}$, sedangkan garis tipis ditemukan dalam posisi sebaliknya sebanyak 10 buah garis dalam setiap satu sentimeter.

Teks naskah MS B berukuran 20 x 13,5 cm. sementara naskahnya sendiri berukuran $23 \times 19 \mathrm{~cm}$ dengan tebal 28 halaman.

Dalam naskah MS B setiap halaman, termasuk halaman terakhir yang berisi kolofon terdapat 21 baris.

${ }^{11}$ Oman Fathurahman, Tanbih al-Masyi; Menyoal Wahdatul Wujud, Kasus Abdurrauf Singkel di Aceh Abad 17, (Bandung: Mizan, 1999), hal. 167-169 
Teks naskah MS B menggunakan bahasa Arab tanpa harakat, dengan gaya khat naskhi yang bernuansa riq'ah. Tulisannya tebal, rapih dan mudah dibaca. Teksnya ditulis dengan tinta hitam, kecuali pada bagian rubrikasi menggunakan tinta merah.

Secara keseluruhan, isi dan sistematika teks MS B sama dengan MS A, yaitu terdiri dari bagian pembukaan, penafsiran wahdatul wujud, ajaran tasawuf Abdurrauf, zikir dan doa serta silsilah guru-guru tarekat Syatariyah dan Qadariyah. ${ }^{12}$

\section{MS C}

Naskah ini terdaftar sebagai kode Cod. Or. 7031 bersama dengan satu teks lainnya, yaitu Syarh Fath al-Rahman. Di bagian depan naskah terdapat tulisan "Legaat Prof. Dr. Snouck Hurgronje 1936". Menurut Oman Fathurahman hal ini memberikan petunjuk bahwa MS C ini pernah dimiliki oleh Snouck Hurgronje. Naskah MS C tersimpan di Universiteitsbibliotheek Leiden.

Dalam kolofon naskah, judul disebut, yaitu Tanbih al-Masyi dengan nama pengarangnya yaitu Abdurrauf Ali al-Jawi, tetapi tidak terdapat tahun penyalinannya. Namun, setelah dianalisa Oman Fathurahman terdapat petunjuk yang mengindikasikan bahwa naskah ini disalin tahun $1889 \mathrm{M}$. jelasnya adalah bahwa di bagian depan naskah terdapat tulisan dalam huruf latin yang menyebutkan bahwa naskah ini disalin dari sebuah naskah milik R. Adi Kesoemo, Cirebon, 1889. Selain itu, dalam kolofon Syarh Fath al-Rahman terdapat informasi mengenai waktu penyalinan naskah, yaitu tahun $1307 \mathrm{H}(1889 \mathrm{M})$.

Oman Fathurahman mendapatkan naskah MS C hanya dalam bentuk microfilm. Namun, ia menduga bahwa alas naskah tersebut berupa kertas dengan ketebalan 68 halaman. Setia halaman terdapat 15 baris, kecuali halaman pertama 13 baris. Halaman terakhir yang memuat kolofon terdapat 16 baris.

Teks MS C ditulis dalam bahasa Arab dengan menggunakan jenis khat naskhi, barisnya teratur rapi dan terdapat harakat pada beberapa kata.

Tulisan menggunakan tinta hitam, kecuali pada bagian rubrikasi terlihat tipis dan diduga oleh Oman menggunakan tinta merah. ${ }^{13}$

\section{MS D}

Naskah MS D merupakan urutan ke-4 dari 16 teks yang didaftarkan sebagai Cod. Or. 7030.

Di bagian depan naskah ini terdapat tulisan "Legaat Prof. Dr. Snouck Hurgronje 1936". Naskah MS D tersimpan di Universiteitsbibliotheek Leiden.

Dalam kolofon naskah MS D tertulis judul Tanbih al-Masyi, dengan nama pengarangnya adalah Abdurrauf bain (?) al-Jawi. Selesai disalin pada hari Rabu. Sementara tahun dan tempat penyalinannya menurut Oman Fathurahman tidak ditemukan. Tetapi di bagian depan naskah terdapat keterangan tentang asal naskah, yaitu Bojonegoro, 1905.

Oman Fathurahman mendapatkan naskah MS D dalam bentuk microfilm.

Ketebalan naskah MS D sebanyak 39 halaman. Setiap halaman terdapat 15 baris, kecuali halaman terakhir yang memuat kolofon, sebanyak 4 baris berbentuk piramida terbalik.

Teks naskah MS D ditulis menggunakan bahasa Arab dengan jenis khat naskhi. Tinta yang digunakan berwarna hitam, kecuali pada bagian rubrikasi menggunakan tinta yang terlihat lebih tipis, dan diduga berwarna merah.

\footnotetext{
${ }^{12}$ Oman Fathurahman, Tanbih al-Masyi; Menyoal Wahdatul Wujud, Kasus Abdurrauf Singkel di Aceh Abad 17, hal. $171-173$

${ }^{13}$ Oman Fathurahman, Tanbih al-Masyi; Menyoal Wahdatul Wujud, Kasus Abdurrauf Singkel di Aceh Abad 17, hal. 
Berbeda dengan ketiga teks sebelumnya, naskah MS D ini setiap kata hampir diberi harakat, terutama pada huruf akhirnya, dan menurut Oman Fathurahman beberapa dari bacaannya banyak yang menyalahi kaidah nahw sharf.

Selain itu, terdapat catatan di sebelah kiri dan kanan teks, dan dijumpai terjemahan beberapa kata yang ditulis di bawah kata tersebut dalam bahasa Jawa dengan menggunakan huruf pegon.

Tidak jauh berbeda dengan ketiga naskah sebelumnya, yaitu bahwa isi teks tersebut terdiri dari bagian pembukaan, inti ajaran tasawuf Abdurrauf, zikir dan doa serta silsilah guru-guru tarekat Syatariyah dan Qadariyah. ${ }^{14}$

\section{KESIMPULAN}

Penelitian yang telah dilakukan Oman Fathurrahman atas teks Tanbih al-Masyi dalam bentuk sebuah buku paling tidak memberikan gambaran di mana seolah-olah generasi sekarang dapat menyaksikan kembali teks tersebut seperti saat ditulis Abdurrauf Singkel, lebih dari tiga ratus tahun lalu. Namun, tentu saja akan lengkap apabila dalam buku tersebut dibahas pula tentang amalan-amalan Syatariyyah yang mengandung rumus-rumus atau simbol-simbol zikir secara lebih utuh, sehingga pemaparannya tidak sekadar lintasan saja. 


\section{DAFTAR PUSTAKA}

Annimarie Schimmel, Dimensi Mistik Dalam Islam, Jakarta; Pustaka Firdaus, 1986

Azyumardi Azra, Jaringan Ulama' Timur Tengah dan Keulauan Nusantara Abad XVII dan XVIII, Bandung; Mizan, 1994

Carl W. Ernst, Mozaik Ajaran Tasawuf, Jakarta; RajaGrafindo Persada, 1999.

J. Spencer Trimingham, The Sufi Order In Islam, London; Oxford New York, 1973

Oman Fathurahman, Tanbih al-Masyi; Menyoal Wahdatul Wujud, Kasus Abdurrauf Singkel di Aceh Abad 17, Bandung: Mizan, 1999

Quraish Shihab et. al., Ensiklopedi Islam, Jakarta; Ikrar Mandiriabadi, 1999

Syafiq A. Mughni, Dinamika Intelektual Islam Pada Abad Kegelapan, Surabaya; LPAM, 2002

The Sufi Order In Islam, London; Oxford New York, 1973 